\title{
Dietary taurine intake, nutrients intake, dietary habits and life stress by depression in Korean female college students: a case-control study
}

Ji-Yeon Park, Jeong-Soon You, Kyung-Ja Chang*

From $17^{\text {th }}$ International Meeting of Taurine

Fort Lauderdale, FL, USA. 14-19 December 2009

\begin{abstract}
Background: The purpose of this study was to investigate the dietary taurine intake, nutrients intake, dietary habits and life stress by depression in Korean female college students.

Methods: In this study, research data were collected in March 2009 and 65 patients with depression and 65 controls without depression participated. The CES-D (Center for Epidemiologic Studies Depression) scale was used for depression measure and controls were matched for age. A 3-day recall method was used for dietary assessment ( 2 weekdays and 1 weekend day).

Results: Average height, weight and body mass index (BMI) were $161.3 \pm 0.5 \mathrm{~cm}, 55.3 \pm 1.0 \mathrm{~kg}$ and $21.2 \pm 0.4 \mathrm{~kg} / \mathrm{m}^{2}$ for depression patients and those of control group were $161.4 \pm 0.7 \mathrm{~cm}, 53.1 \pm 0.8 \mathrm{~kg}$ and $20.3 \pm 0.2 \mathrm{~kg} / \mathrm{m}^{2}$, respectively. Average dietary taurine intakes of depression patients and control group were 89.1 and $88.0 \mathrm{mg} /$ day, respectively. There was no significant difference in dietary taurine intake between depression patients and control group. The average intakes of vitamin $A(p<0.05)$, $\beta$-carotene $(p<0.01)$, vitamin $C(p<0.05)$, folic acid $(p<0.05)$ and fiber $(p<0.05)$ of depression patients were significantly lower compared to control group. The average total dietary habit score of depression patients (47.2) was significantly lower than that of control group (51.3) $(p<0.01)$. The average dietary habit scores of "eating meals at regular times" ( $p<0.05)$, "eating adequate amount of meals" ( $p<0.05)$, "having meals with diverse foods" $(p<0.05)$, "avoiding eating spicy foods" ( $p<0.01)$ and "eating protein foods such as meat, fish, eggs, beans more than 2 times a day" ( $p<0.05)$ were significantly lower in depression patients compare to control group. The average scores of total life stress $(p<0.001)$ and all stress categories of depression patients were significantly higher than those of control group except faculty problem score.

Conclusions: These results show that depression patients have poor dietary habits and unbalanced nutrition status. Also depression patients have higher life stress score.

Therefore, continuous nutrition education and counselling for good dietary habits and balanced nutrition status are needed to prevent depression in Korean college students.
\end{abstract}

\section{Background}

Depression is an usual emotional disability that leads to distress and seriously damages daily functioning $[1,2]$. Depression is typically more common in women than men [3] because women have higher stress levels and lower achievement levels than men in gender roles [4].

\footnotetext{
* Correspondence: kjchang@inha.ac.kr

Dept. of Food and Nutrition, Inha University, Incheon 402-753, Korea

Full list of author information is available at the end of the article
}

Depression in the college student is a significant problem [5], and depression students have problems in academic work and motivation [6].

Overall nutritional status and nutrients intake are associated with depression, and poor diet quality is the leading causes of depression [7]. A study of childhood showed that food insufficiency has been connected with behavior problems such as depression, aggression and anxiety [8]. It was reported that higher depression level 
is associated with less regular meals in the adolescents [9]. Depression is closely associated with stress. The stress situation can cause or aggravate depression [10], and adolescent girls respond to general stressors with greater depression [11]. Taurine is an important role as an inhibitory neurotransmitter [12] and is essential for neuronal growth in human body [13]. Taurine is associated with emotional disturbances such as depression [14] and anxiety [15]. It was reported that plasma level of taurine was increased in depression patients [16] and in schizophrenia [17]. However, little information is available on the relationship between depression and dietary taurine intake in humans. Therefore, the purpose of this study was to investigate the relation among depression, dietary taurine intake, nutrients intake, dietary habits and life stress in Korean female college students.

\section{Methods}

\section{Subjects}

Research data were collected in March 2009 and the subjects were 130 female college students residing in the Incheon area. A case-control study was conducted using a questionnaire. The depression group was composed of 65 female college students with depression, and the control group consisted of 65 female college students without depression. Depression was measured by the Korean version of CES-D (Center for Epidemiologic Studies Depression) scale [18]. The CES-D scale, a 20-item selfreporting measure, is 4-point scale ranging from 0 to 3 with a total score of 0-60. Depression is defined as CES$\mathrm{D}$ score of 16 and healthy controls were matched for age. Greater and higher scores indicated higher depressed levels. Subjects submitted to the researcher a written and signed informed consent form to take part in this survey.

\section{Questionnaire}

The dietary habits questionnaire included 16 items which were based on previous studies [19,20]. Each item responses ranged from 1 to 5 and the scores of items

Table 1 General characteristics of the subjects

\begin{tabular}{lcc}
\hline Variables & $\begin{array}{c}\text { Depression patients } \\
(\mathbf{n}=\mathbf{6 5})\end{array}$ & $\begin{array}{c}\text { Control group } \\
(\mathbf{n}=\mathbf{6 5})\end{array}$ \\
\hline Age (years) & $20.6 \pm 0.2$ & $20.5 \pm 0.2$ \\
Height $(\mathrm{cm})$ & $161.3 \pm 0.5$ & $161.4 \pm 0.7$ \\
Weight $(\mathrm{kg})$ & $55.3 \pm 1.0$ & $53.1 \pm 0.8$ \\
BMl $\left(\mathrm{kg} / \mathrm{m}^{2}\right)$ & $21.2 \pm 0.4^{*}$ & $20.3 \pm 0.2$ \\
Soft lean mass $(\mathrm{kg})$ & $36.9 \pm 0.5$ & $36.3 \pm 0.5$ \\
Body fat percentage (\%) & $28.7 \pm 0.6$ & $27.2 \pm 0.5$ \\
WHR & $0.81 \pm 0.0$ & $0.80 \pm 0.0$ \\
BMR & $1398.6 \pm 12.7$ & $1383.0 \pm 13.6$ \\
\hline
\end{tabular}

Values are mean $\pm S E$; BMI: body mass index; ${ }^{*}: p<0.05,{ }^{* *}: p<0.01,{ }^{* * *}$ : $p<0.001$ (by Student's t-test); WHR: waist-hip ratio; BMR: basal metabolic rate
Table 2 Dietary taurine intake of the subjects

\begin{tabular}{lcc}
\hline Variables & $\begin{array}{c}\text { Depression patients } \\
(\mathbf{n}=65)\end{array}$ & $\begin{array}{c}\text { Control group } \\
(\mathbf{n}=65)\end{array}$ \\
\hline $\begin{array}{l}\text { Taurine }(\mathrm{mg} / \\
\text { day) }\end{array}$ & $89.0 \pm 8.5^{\mathrm{NS}}$ & $88.0 \pm 7.5$ \\
\hline
\end{tabular}

Values are mean $\pm \mathrm{SE} ; \mathrm{NS}$ : not significant

negatively worded were reversed before summation. The life stress scale contained 50 items about their experience frequency and importance of stress, and the response to each item was scored on a 4-point scale from 0 to 3 during the past year [21]. The total life stress score was calculated by multiplying frequency of stress experienced and importance of stress. The higher stress scores are indicative of greater frequency of stress experienced and importance of stress.

\section{Anthropometric measurement and body composition}

The subject's height was measured using a stadiometer. Measurement of weight, calculation of body mass index (BMI), soft lean mass, body fat percentage, waist-hip ratio (WHR) and calculation of basal metabolic rate (BMR) were measured with the InBody 3.0 Body Composition Analyzer (InBody 3.0, Biospace, Seoul, Korea).

Table 3 Nutrients intake of the subjects

\begin{tabular}{|c|c|c|}
\hline Variables & $\begin{array}{c}\text { Depression patients } \\
(n=65)\end{array}$ & $\begin{array}{c}\text { Control group } \\
(n=65)\end{array}$ \\
\hline Energy (kcal/day) & $1524.5 \pm 46.5$ & $1488.4 \pm 42.2$ \\
\hline $\begin{array}{l}\text { Carbohydrate (g/ } \\
\text { day) }\end{array}$ & $200.2 \pm 6.7$ & $203.7 \pm 6.2$ \\
\hline Total fat (g/day) & $52.6 \pm 2.0$ & $50.7 \pm 2.0$ \\
\hline Total protein (g/day) & $59.2 \pm 2.2$ & $58.6 \pm 1.9$ \\
\hline $\begin{array}{l}\text { Vitamin A ( } \mu \mathrm{g} \text { RE/ } \\
\text { day) }\end{array}$ & $539.5 \pm 27.6^{*}$ & $641.3 \pm 27.0$ \\
\hline$\beta$-carotene (mg/day) & $2076.6 \pm 151.5^{* *}$ & $2656.0 \pm 131.1$ \\
\hline Vitamin $B_{1}$ (mg/day) & $1.0 \pm 0.0$ & $1.0 \pm 0.0$ \\
\hline Vitamin $B_{2}$ (mg/day) & $0.9 \pm 0.0$ & $0.9 \pm 0.0$ \\
\hline Vitamin $B_{6}$ (mg/day) & $1.4 \pm 0.1$ & $1.5 \pm 0.1$ \\
\hline Niacin (mg NE/day) & $13.4 \pm 0.6$ & $12.9 \pm 0.4$ \\
\hline Vitamin C (mg/day) & $52.4 \pm 3.2^{*}$ & $66.2 \pm 4.9$ \\
\hline Vitamin E (mg/day) & $11.2 \pm 0.5$ & $11.9 \pm 0.5$ \\
\hline $\begin{array}{l}\text { Phosphorous (mg/ } \\
\text { day) }\end{array}$ & $793.8 \pm 26.1$ & $776.1 \pm 22.5$ \\
\hline Calcium (mg/day) & $409.6 \pm 17.5$ & $372.1 \pm 16.2$ \\
\hline Iron (mg/day) & $9.6 \pm 0.4$ & $9.9 \pm 0.4$ \\
\hline Zinc (mg/day) & $6.7 \pm 0.2$ & $6.9 \pm 0.2$ \\
\hline Folic acid ( $\mu \mathrm{g} /$ day) & $151.8 \pm 6.5^{*}$ & $172.1 \pm 7.7$ \\
\hline Fiber (g/day) & $12.1 \pm 0.4^{*}$ & $13.5 \pm 0.5$ \\
\hline Ash (g/day) & $12.5 \pm 0.4$ & $13.4 \pm 0.5$ \\
\hline Potassium (mg/day) & $1794.4 \pm 62.1$ & $1788.8 \pm 63.2$ \\
\hline Sodium (mg/day) & $2874.2 \pm 115.4$ & $3017.4 \pm 123.0$ \\
\hline Cholesterol (mg/day) & $268.8 \pm 14.2$ & $295.7 \pm 15.1$ \\
\hline
\end{tabular}


Table 4 Dietary habits scores of the subjects

\begin{tabular}{lcc}
\hline Variables & Depression patients (n=65) & Control group (n=65) \\
\hline Eating breakfast regularly & $3.3 \pm 0.2$ & $3.4 \pm 0.2$ \\
Eating meals at constant times & $2.7 \pm 0.1^{*}$ & $3.1 \pm 0.1$ \\
Eating meals slowly & $2.8 \pm 0.2$ & $3.1 \pm 0.1$ \\
Eating adequate amount of meals & $3.4 \pm 0.1^{*}$ & $3.7 \pm 0.1$ \\
Eating three meals a day & $2.8 \pm 0.2$ & $3.1 \pm 0.2$ \\
Having meals with diverse foods & $3.1 \pm 0.1^{*}$ & $3.4 \pm 0.1$ \\
Avoiding overeating everyday & $2.6 \pm 0.1$ & $2.9 \pm 0.1$ \\
Avoiding eating salty foods & $2.8 \pm 0.2$ & $3.2 \pm 0.1$ \\
Avoiding eating spicy foods & $2.5 \pm 0.2^{* *}$ & $3.1 \pm 0.2$ \\
Eating foods such as meat, fish, eggs, beans more than 2 times a day & $2.9 \pm 0.1^{*}$ & $3.3 \pm 0.1$ \\
Avoiding eating foods containing oil or mayonnaise more than 2 times a day & $3.7 \pm 0.1$ & $3.7 \pm 0.1$ \\
Eating dairy foods (milk, yogurt, etc.) everyday & $3.2 \pm 0.2$ & $3.0 \pm 0.2$ \\
Eating greenish yellow vegetable every meals & $2.9 \pm 0.1$ & $3.1 \pm 0.1$ \\
Eating fruit everyday & $2.8 \pm 0.1$ & $3.0 \pm 0.1$ \\
Avoiding eating sweet foods(snack, chocolate, etc.) everyday & $3.1 \pm 0.1$ & $3.1 \pm 0.1$ \\
Applying nutrition knowledge to daily life & $2.9 \pm 0.0$ & $3.2 \pm 0.1$ \\
Total score & $47.2 \pm 0.9^{* *}$ & $51.3 \pm 0.9$ \\
\hline
\end{tabular}

Values are mean $\pm \mathrm{SE}^{*}: \mathrm{p}<0.05,{ }^{* *}: \mathrm{p}<0.01,{ }^{* * *}: \mathrm{p}<0.001$ (by Student's t-test)

\section{Intakes of dietary taurine and nutrients}

A 3-day recall method was used for dietary assessment ( 2 weekdays and 1 weekend day). Dietary taurine and nutrients intakes were estimated using the computeraided nutrition program (CAN-pro 3.0, The Korean Nutrition Society, Korea) inputed with a taurine content database for 17 food groups, commonly used 321 food items [22,23].

\section{Statistical analysis}

The statistical analysis was conducted using the SPSS 12.0 program. Mean and standard error were calculated for all variables. The data obtained between depression group and control group were compared by Student's t-test.

Table 5 Life stress scores of the subjects

\begin{tabular}{lcc}
\hline Variables & $\begin{array}{c}\text { Depression patients } \\
(\mathbf{n}=65)\end{array}$ & $\begin{array}{c}\text { Control group } \\
(\mathbf{n}=65)\end{array}$ \\
\hline Interpersonal relationship & & \\
stress & & \\
$\quad$ Faculty problem & $7.5 \pm 1.3$ & $5.6 \pm 1.1$ \\
$\quad$ Lover problem & $7.5 \pm 1.6^{*}$ & $3.3 \pm 0.9$ \\
$\quad$ Friend problem & $5.7 \pm 1.1^{* *}$ & $1.9 \pm 0.6$ \\
$\quad$ Family problem & $12.5 \pm 2.3^{* *}$ & $3.9 \pm 1.1$ \\
Task-related stress & & \\
$\quad$ Grade problem & $29.5 \pm 2.8^{*}$ & $19.7 \pm 2.5$ \\
$\quad$ Future problem & $32.8 \pm 2.9^{* * *}$ & $16.4 \pm 1.8$ \\
$\quad$ Economy problem & $24.4 \pm 3.2^{* * *}$ & $7.9 \pm 1.3$ \\
$\quad$ Value problem & $26.6 \pm 2.7^{* * *}$ & $10.5 \pm 1.8$ \\
Total score & $87.0 \pm 6.3^{* * *}$ & $41.7 \pm 4.2$ \\
\hline
\end{tabular}

Values are mean $\pm S E ;{ }^{*}: p<0.05,{ }^{* *}: p<0.01,{ }^{* * *}: p<0.001$ (by Student's t-test)

\section{Results}

\section{General characteristics}

General characteristic data of the subjects are shown in Table 1. The average height, weight and BMI were $161.3 \mathrm{~cm}, 55.3 \mathrm{~kg}$ and $21.2 \mathrm{~kg} / \mathrm{m}^{2}$ for depression patients and those of controls were $161.4 \mathrm{~cm}, 53.1 \mathrm{~kg}$ and $20.3 \mathrm{~kg} /$ $\mathrm{m}^{2}$, respectively. According to the 4th Korea National Health and Nutrition Examination Survey, the average height, weight and BMI of 19-29 years old women were $161.4 \mathrm{~cm}, 56.4 \mathrm{~kg}$ and $21.6 \mathrm{~kg} / \mathrm{m}^{2}$, respectively [24]. The average height, weight and BMI of our subjects were similar to those of the same age group in Korean women. There was significant difference in BMI between depression patients and control group. In the previous studies $[25,26]$, depression was significantly associated with higher BMI in women. Also it was reported that a higher BMI may lead to depression in males but the relationship may not be the same in females [27].

\section{Intakes of dietary taurine and nutrients}

Average dietary taurine intake of depression patients and control group was 89.1 and $88.0 \mathrm{mg} /$ day, respectively (Table 2). The daily taurine intake of female college students in Korea was 96.9 mg/day [28]. There was no significant difference in dietary taurine intake between depression patients and control group. It was reported that serum concentrations of taurine was also not significantly different between depression patients and control group [29]. Nutrients intakes of the subjects are shown in Table 3 . The average intakes of vitamin $A$ $(\mathrm{p}<0.05), \beta$-carotene $(\mathrm{p}<0.01)$, vitamin $\mathrm{C}(\mathrm{p}<0.05)$, folic 
acid $(\mathrm{p}<0.05)$ and fiber $(\mathrm{p}<0.05)$ of depression patients were significantly lower compared to control group. The average intakes of carbohydrate, vitamin $\mathrm{B}_{6}$, vitamin $\mathrm{E}$, iron, zinc, sodium and cholesterol of depression patients were lower compared to control group, but not significantly. It was reported that iron, zinc, and selenium intakes were deficient in depression patients [7]. In addition, folic acid and vitamin $B_{12}$ deficiency were associated with depressive disorders and the patients with severe depression had low folic acid and low vitamin $\mathrm{B}_{12}$ levels in blood [30].

\section{Dietary habits}

Table 4 shows the average dietary habit scores of depression patients and control group. There was significant difference in the average total dietary habits score between depression patients and control group; those of depression patients and control group were 47.2 and 51.3 , respectively $(\mathrm{p}<0.01)$. The average scores of "eating meals at constant times" $(\mathrm{p}<0.05)$, "eating adequate amount of meals" ( $<<0.05)$, "having meals with diverse foods" $(\mathrm{p}<0.05)$, "avoiding eating spicy foods" $(\mathrm{p}<0.01)$ and "eating protein foods such as meat, fish, eggs, beans more than 2 times a day" $(\mathrm{p}<0.05)$ were significantly lower in depression patients compared to control group. It was reported that female high school students with depression had poor food behaviour [31].

\section{Life stress}

Life stress levels of the subjects are shown in Table 5 . The average scores of total life stress $(\mathrm{p}<0.001)$ and all stress categories of depression patients were significantly higher than those of control group except faculty problem score. It was reported that depression in middleaged Korean women was significantly associated with psychological stress and physical stress [32].

\section{Conclusions}

Our study investigated the relation among depression, dietary taurine intake, nutrients intake, dietary habits and life stress. The average intakes of vitamin $A, \beta$-carotene, vitamin $C$, folic acid, fiber of depression patients were significantly lower compared to control group. The average total dietary habit score of depression patients was significantly lower and total life stress score of depression patients was significantly higher compared to control group. However, there was no significant difference in dietary taurine intake between depression patients and control group. These results show that depression patients have poor dietary habits and unbalanced nutrition status. Therefore, continuous nutrition education and counselling for good dietary habits and balanced nutrition status are needed to prevent depression in Korean college students.

\section{Abbreviations}

CES-D: Center for Epidemiologic Studies Depression; BMI: body mass index; WHR: waist-hip ratio; BMR: basal metabolic rate.

\section{Acknowledgements}

This article has been published as part of Journal of Biomedical Science Volume 17 Supplement 1, 2010: Proceedings of the 17th International Meeting of Taurine. The full contents of the supplement are available online at http://www.jbiomedsci.com/supplements/17/S1.

This work was supported by INHA UNIVERSITY Research Grant.

\section{Authors' contributions}

JYP carried out the data collection, performed the statistical analysis and drafted the manuscript. JSY participated in its design and coordination and helped to draft the manuscript. KJC supervised the design and execution of the study. All authors read and approved the final manuscript.

\section{Competing interests}

The authors declare that they have no competing interests.

Published: 24 August 2010

\section{References}

1. Khawaja N, Bryden K: The development and psychometric investigation of the university student depression inventory. Journal of affective disorders 2006, 96:21-29.

2. Manning W Jr., Wells K: The effects of psychological distress and psychological well-being on use of medical services. Medical care 1992, 30:541-553.

3. Hankin B, Mermelstein R, Roesch L: Sex differences in adolescent depression: Stress exposure and reactivity models. Child development 2007, 78:279-295.

4. Kessler R: Epidemiology of women and depression. Journal of affective disorders 2003, 74:5-13.

5. Paik JW, Song JY: Special Editions : Depression in the College student. Kyung Hee Univ Med Cent 2009, 25:1-6.

6. Lyubomirsky S, Kasri F, Zehm K: Dysphoric rumination impairs concentration on academic tasks. Cognitive Therapy and Research 2003, 27:309-330.

7. Bodnar L, Wisner K: Nutrition and depression: implications for improving mental health among childbearing-aged women. Biological Psychiatry 2005, 58:679-685.

8. Murphy J, Wehler C, Pagano M, Little M, Kleinman R, Jellinek M: Relationship between hunger and psychosocial functioning in lowincome American children. J Am Acad Child Adolesc Psychiatry 1998, 37:163-170.

9. Fulkerson J, Sherwood N, Perry C, Neumark-Sztainer D, Story M: Depressive symptoms and adolescent eating and health behaviors: a multifaceted view in a population-based sample. Preventive Medicine 2004, 38:865-875.

10. Pittenger C, Duman R: Stress, depression, and neuroplasticity: a convergence of mechanisms. Neuropsychopharmacology 2008, 33:88-109.

11. Rudolph KD: Gender differences in emotional responses to interpersonal stress during adolescence. Journal of Adolescent Health 2002, 30:3-13.

12. Park TS: Review: Taurine - Its Physiological Roles and Nutritional Significance. Korean J Nutr 2001, 34:597-607.

13. Chen $X$, Pan Z, Liu D, Han X: Effect of taurine on human fetal neuron cells: proliferation and differentiation. Adv Exp Med Biol 1998, 442:397-403.

14. Mauri M, Ferrara A, Boscati L, Bravin S, Zamberlan F, Alecci M, Invernizzi G: Plasma and platelet amino acid concentrations in patients affected by major depression and under fluvoxamine treatment. Neuropsychobiology 1998, 37:124-129.

15. Chen SW, Kong WX, Zhang YJ, Li YL, Mi XJ, Mu XS: Possible anxiolytic effects of taurine in the mouse elevated plus-maze. Life Sciences 2004, 75:1503-1511.

16. Altamura C, Maes M, Dai J, Meltzer H: Plasma concentrations of excitatory amino acids, serine, glycine, taurine and histidine in major depression. European Neuropsychopharmacology 1995, 5:71-75.

17. Bjerkenstedt L, Edman G, Hagenfeldt L, Sedvall G, Wiesel F: Plasma amino acids in relation to cerebrospinal fluid monoamine metabolites in schizophrenic patients and healthy controls. The British Journal of Psychiatry 1985, 147:276-282. 
18. Chon KK, Rhee MK: Preliminary Development of Korean Version of CES-D. Korean Journal of Clinical Psychology 1992, 11:65-76.

19. Song YS: The Effect of Nutrition Course on the Nutrition Knowledge and Food Habits in College Students. Korean J Nutr 1986, 19:420-426.

20. Lee YN, Choi H: A Study on the Relationship between Body Mass Index and the Food Habits of College Students. KOREAN J DIETARY CULTURE 1994, 9:1-10.

21. Chon KK, Kim K-H, Yi J: Development of the Revised Life Stress Scale for College Students. Korean Journal of Health Psychology 2000, 5:316-335.

22. Kim ES, Kim JS, Moon HK: Taurine Contents in Commercial Milks, Meats and Seafoods. J Korean Soc Food sci Nutr 1999, 28:16-21.

23. Park TS: Studies on novel activities of taurine and the development of taurine content database of foods. Final Reports of Korean Health Research and Development Project 2000, 99-106.

24. Welfare $\mathrm{MoH}$ : The fourth korea national health \& nutrition examination survey. 2008.

25. Onyike C, Crum R, Lee H, Lyketsos C, Eaton W: Is obesity associated with major depression? Results from the Third National Health and Nutrition Examination Survey. American Journal of Epidemiology 2003, 158:1139-1147.

26. Rasgon N, Rao R, Hwang S, Altshuler L, Elman S, Zuckerbrow-Miller J, Korenman S: Depression in women with polycystic ovary syndrome: clinical and biochemical correlates. Journal of affective disorders 2003, 74:299-304.

27. Dragan A, Akhtar-Danesh N: Relation between body mass index and depression: a structural equation modeling approach. BMC Medical Research Methodology 2007, 7:17.

28. Sung MJ, Chang KJ: Correlations Between Dietary Taurine Intake and Life Stress in Korean College Students. Adv Exp Med Biol 2009, 643:423-428.

29. Maes $M$, Verkerk $R$, Vandoolaeghe $E$, Lin $A$, Scharpe $S$ : Serum levels of excitatory amino acids, serine, glycine, histidine, threonine, taurine, alanine and arginine in treatment-resistant depression: modulation by treatment with antidepressants and prediction of clinical responsivity. Acta Psychiatr Scand 2007, 97:302-308.

30. Coppen A, Bolander-Gouaille C: Treatment of depression: time to consider folic acid and vitamin B12. Journal of Psychopharmacology 2005, 19:59.

31. Park JE, Kim SJ, Choue R: Study on Stress, Depression, Binge Eating, and Food Behavior of High School Girls Based on Their BMI. Korean J Community Nutrition 2009, 14:175-181.

32. Lee S-S, Choi W-H: The Relationship between Depression and Stress in Korean Middle-Aged Women. J Korean Soc Matern Child Health 2007, 11:185-196.

doi:10.1186/1423-0127-17-S1-S40

Cite this article as: Park et al.: Dietary taurine intake, nutrients intake, dietary habits and life stress by depression in Korean female college students: a case-control study. Journal of Biomedical Science 201017 (Suppl 1):S40.

\section{Submit your next manuscript to BioMed Central and take full advantage of:}

- Convenient online submission

- Thorough peer review

- No space constraints or color figure charges

- Immediate publication on acceptance

- Inclusion in PubMed, CAS, Scopus and Google Scholar

- Research which is freely available for redistribution

Submit your manuscript at www.biomedcentral.com/submit 